\title{
Regional Non-point Source Pollution Control Method: A Design of Ecological Compensation Standards
}

\author{
Shibao $L u^{1}$, Weijun Zhong ${ }^{2 *}$, Wei $L i^{2}$ and Farhad Taghizadeh-Hesary ${ }^{3 *}$ \\ ${ }^{1}$ School of Political Science and Public Administration, Neijiang Normal University, Nei Jiang, China, ${ }^{2}$ School of Public \\ Administration, Zhejiang University of Finance and Economics, Hang Zhou, China, ${ }^{3}$ Tokai University, Hiratsuka, Japan
}

\section{OPEN ACCESS}

Edited by:

Faik Bilgili,

Erciyes University, Turkey

Reviewed by:

Sevda Kuşkaya,

Erciyes University, Turkey

Yacouba Kassouri,

Leipzig University, Germany

*Correspondence:

Weijun Zhong

zhongwj@zufe.edu.cn

Farhad Taghizadeh-Hesary

farhad@tsc.u-tokai.ac.jp

Specialty section:

This article was submitted to

Environmental Economics and

Management,

a section of the journal

Frontiers in Environmental Science

Received: 13 June 2021

Accepted: 30 August 2021

Published: 17 September 2021

Citation:

Lu S, Zhong W, Li W and Taghizadeh-Hesary F (2021) Regional Non-point Source Pollution Control Method: A Design of Ecological

Compensation Standards.

Front. Environ. Sci. 9:724483.

doi: $10.3389 /$ fenvs.2021.724483
Reasonable ecological compensation standard is the key to solve farmland non-point source pollution. In the design of compensation standards, the current investigation included ecological benefits in selecting the experimental method. The Multinomial Logit model is used to analyze the willingness of farmers to receive compensation for non-point source pollution control of cultivated land. The results are as follows: 1) Financial compensation can effectively stimulate farmers' willingness to control non-point source pollution. 2) The willingness of farmers to participate in the ecological compensation is greater when there prevails a higher level of risk preferences and higher understanding of farmland non-point source pollution control policy. Also, willingness is higher in younger, highly educated, and highly involved in a part-time family business with higher recognition degree in the ecological function of farmland non-point source pollution control. 3) The difference in treatment measures and compensation methods should be included in the standard compensation design. Therefore, the design of the ecological compensation standard should take into account the economic loss and ecological benefits of farmers at the same time, and environmental protection publicity and education for farmers can also be carried out with the help of modern media.

Keywords: cultivated land non-point pollution, pollution control, ecological benefit, environmental protection, compensation standard

\section{INTRODUCTION}

The cultivated land provides people with a survival guarantee and provides peasant households with an employment guarantee. The cultivated land has economic and social value in China with a large agricultural population and plays an essential role in social stability (Ozdemir, 2020; Sharma and Mahajan, 2019). Meanwhile, the cultivated land also has ecological benefits such as water conservation, climate regulation, and biodiversity maintenance. However, with the socioeconomic development, peasant households use a large number of chemical fertilizers and pesticides to pursue higher agricultural output, which inevitably leads to the issue of non-point source pollution ${ }^{1}$ of cultivated land (Lu et al., 2020a). The cultivated land is a non-renewable resource with high pollution frequency, wide harm range, and control difficulty. Thus it has gradually evolved

\footnotetext{
${ }^{1}$ It mean diffusion of contamination or pollution in the water/air that does not originate from a single discrete source. This type of pollution is often cause cumulative effect of small amounts of contaminants that dispersed on a large area. For example excess use of fertilizers, herbicides and insecticides diffuse in agricultural lands and air
} 
into a worldwide issue. To ensure the sustainable and sound development of China's agriculture, non-point source pollution of cultivated land needs to be solved urgently.

In terms of the causes of pollution, reducing the use of chemical fertilizers and pesticides and the discharge of agricultural wastes from the source is the most effective measure to improve the ecological value of the cultivated land system. However, peasant households' enthusiasm for adopting the source mentioned above is low due to the shortage of technology and the risk of yield reduction (Valentine, 2014). Therefore, ecological compensation has become an effective economic means to adjust the relationship between stakeholders and realize the internalization of external benefits. Peasant households are mainly encouraged to actively reduce the application of chemical fertilizers and pesticides and reduce agricultural waste discharge in the production process by giving them economic compensation, thereby promoting the coordinated development of cultivated land ecosystem protection and peasants' steady and increasing income. Therefore, adopting ecological compensation standards by considering the ecological benefits is a suitable method that shows the motivation of doing this research.

Ecological footprint cause ravid environmental degradation (Ulucak et al., 2020). Stated that ecological footprint caused rapid environmental degradation and discriminated liabilities for countries, while the government remains unnoticed environmental conservation either in policy priorities and in academic literature. Moreover (Kassouri and Altıntaş, 2020), highlighted the strong association between ecological footprints and human development from the panel data of thirteen countries and demonstrated that economic institutions can play a crucial role in the mitigation of such trade-off (Zheng et al., 2021). suggested the mechanism of ecological compensation for the solution of environmental and economic dilemmas in order to achieve sustainable development. By using panel data, their results showed that industrial areas tend to be advanced and rational after the implementation of the ecological compensation policy.

The concept of ecological compensation was put forward with the outbreak of the environmental crisis in western countries in the 1960s and 1970s (Lu et al., 2016; Meng et al., 2016). With the continuous improvement of material living standards, the ecological environment was also extensively damaged. Thus people began to explore the path of sustainable development, and all sectors of society raised ecological compensation (Gao et al., 2019; Lu et al., 2020b). China's industrialization process starts late, but the deterioration rate of the ecological environment in China in recent years is no less than that of western developed countries, which seriously threatens people's safety and future development. Therefore, China pays more and more attention to the research on ecological compensation issues and carries out many practical activities.

As for the research on ecological compensation of cultivated land, some studies in the U.S. show that fallow is the main way for soil protection (Xu et al., 2019; Chen et al., 2020a). Peasant households can apply to the government and sign long-term contracts according to their actual situation and wish to convert those ecologically fragile cultivated land into grassland and woodland or stop farming. The European Union (EU) implements graded ecological compensation for cultivated land. Baylis $\mathrm{K}$ stated that each EU member state determines its minimum level of good farming practice (GFP) and obtains government subsidies in the first stage, including agricultural subsidies and price support (Chen et al., 2018). Peasants can obtain more subsidy support accordingly if making continuous efforts to increase GFP beyond the baseline level. In this way, the EU ecological compensation of cultivated land has a strong correlation with the quality of cultivated land. The higher the quality of cultivated land, the more compensation can be obtained. According to the practice, this policy can better encourage peasants to improve cultivated land quality and protect cultivated land resources.

There are some foreign experiences in ecological compensation that we can learn from (Lu et al., 2021; Zhao et al., 2021). For example, it systematically explains why compensation shall be made and who shall make compensation in theory. However, the compensation standard cannot be copied due to the different national and agricultural conditions. Many domestic scholars have drawn lessons from the research results of foreign scholars in their theoretical discussions on related issues. At the same time, the compensation standards are quite different according to their different research fields and time and space (Deng et al., 2017; Guan et al., 2018). Given the research trends of ecological compensation in China and other countries, this paper will fully absorb the experience of ecological compensation in various fields in China and other countries. The actual situation will be introduced into the design of compensation standards for non-point source pollution control of cultivated land.

Therefore, it is necessary to formulate a reasonable compensation standard for non-point source pollution control of cultivated land to generate effective incentives for peasant households and conform to the principle of minimizing social expenditure. The various costs of peasant households' ecological protection behavior and the value of cultivated land ecosystem obtained by peasant households due to environmental improvement shall be considered in the compensation standard to avoid the low compensation efficiency caused by high compensation standards. It is difficult to evaluate the ecological benefits of cultivated land by the existing market value evaluation methods. Thus the selection experiment method, that is, the non-market value evaluation method based on the hypothetical market will be used in this paper to quantify the economic losses and ecological benefits obtained by peasant households in the process of non-point source pollution control of cultivated land, and then to obtain the ecological compensation standard for non-point source pollution control of cultivated land that takes into account the interests of peasant households and the principle of minimizing social expenditure.

\section{THEORETICAL ANALYSIS AND RESEARCH METHODS Necessity of Considering Ecological Benefits in Compensation Standards}

Peasant households enjoy the ecosystem value of cultivated land while participating in pollution control of cultivated land ( $\mathrm{Lu}$ 
et al., 2019a). To maximize the effectiveness of control policies, it is necessary to incorporate ecological benefits into the compensation standard for non-point source pollution control of cultivated land.

Assuming that the utility function of peasant households is $U$ $=\mathrm{U}(\mathrm{A}, \mathrm{E})$, the production function of agricultural products is $\mathrm{F}$ $(\mathrm{X})$, and the production function of ecological products is $\mathrm{G}(\mathrm{Y})$. Where, A represents the net income of agriculture, E represents the ecological products provided by non-point source pollution control of cultivated land, $\mathrm{X}$ is the input factor of agricultural product production, its unit cost is $\mathrm{W}, \mathrm{Y}$ is the input factor of non-point source pollution control of cultivated land, and its unit cost is R. In addition, assuming that $\mathrm{P} 1$ is the price vector of unit agricultural products and P2 is the price vector of ecological products, its economic meaning is the ecological benefits obtained by peasant households. Utility function $\mathrm{U}(\mathrm{A}, \mathrm{E})$, production function of agricultural products $\mathrm{F}(\mathrm{X})$, and production function of ecological products $\mathrm{G}(\mathrm{Y})$ are monotone increasing concave functions respectively. To ensure the accuracy of the theoretical model, the following assumptions are put forward in this paper:

H1: Peasant households are rational economic men who clearly understand their wishes, preferences, and behavior results, and the purpose of their economic behavior is to maximize welfare.

$\mathrm{H} 2$ : There is only one peasant household in the market, and the ecological products $\mathrm{E}$ enjoyed by the peasant household depend on the number of ecological products $G(Y)$ provided by individuals; thus there is $\mathrm{E}=\mathrm{G}(\mathrm{Y})$.

$\mathrm{H} 3$ : Assuming that the benchmark state $\mathrm{t}=0$, the agricultural income is $\mathrm{A}=\mathrm{A} 0$, the input for non-point source pollution control of cultivated land is $\mathrm{Y} 0=0$, that is, $\mathrm{G}(\mathrm{Y} 0)=0$, and the utility level before participating in non-point source pollution control of cultivated land is $\mathrm{U} 0$; at the time of $\mathrm{t}=1$ for ecological compensation of non-point source pollution control of cultivated land, $\mathrm{A} \geq \mathrm{A} 0, \mathrm{Y} \geq 0, \mathrm{U} \geq \mathrm{U} 0$.

The basic principle of ecological compensation is that the welfare level of peasant households will not decline after participating in the non-point source pollution control of cultivated land (Guan et al., 2018). Therefore, the economic model for peasant households to participate in the decisionmaking of non-point source pollution control of cultivated land is as follows:

$$
\left\{\begin{array}{l}
\operatorname{Max} U(A, E) \\
\text { s.t.P1F(X) }+P 2 G(Y)-W X-R Y \geq A 0 \\
X, Y \geq 0
\end{array}\right.
$$

Forming a Lagrangian Function:

$$
\mathrm{L}=\mathrm{U}(\mathrm{A}, \mathrm{E})+\lambda[\mathrm{P} 1 \mathrm{~F}(\mathrm{X})+\mathrm{P} 2 \mathrm{G}(\mathrm{Y})-\mathrm{WX}-\mathrm{RY}-\mathrm{A} 0]
$$

According to Kuhn-Tucker first-order conditions, we can obtain the following:

$$
\frac{\partial \mathrm{L}}{\partial \mathrm{X}} \leq 0, \mathrm{X} \geq 0, \text { and } \mathrm{X} \frac{\partial \mathrm{L}}{\partial \mathrm{X}}=0
$$

$$
\begin{aligned}
& \frac{\partial \mathrm{L}}{\partial \mathrm{Y}} \leq 0, \mathrm{Y} \geq 0, \text { and } \mathrm{Y} \frac{\partial \mathrm{L}}{\partial \mathrm{Y}}=0 \\
& \frac{\partial \mathrm{L}}{\partial \lambda} \geq 0, \lambda \geq 0, \text { and } \lambda \frac{\partial \mathrm{L}}{\partial \lambda}=0
\end{aligned}
$$

According to the principle of complementary slackness, when $=0$ and $\mathrm{X}>0, \mathrm{Y}>0$ :

$$
\begin{gathered}
\frac{\partial \mathrm{L}}{\partial \mathrm{X}}=\frac{\partial \mathrm{UA}}{\partial \mathrm{A}}\left[\mathrm{P} 1 \mathrm{~F}^{\prime}(\mathrm{X})-\mathrm{W}\right]=0 \\
\frac{\partial \mathrm{L}}{\partial \mathrm{Y}}=\frac{\partial \mathrm{UA}}{\partial \mathrm{A}}[\mathrm{P} 2 \mathrm{G}(\mathrm{X})-\mathrm{R}]+\frac{\partial \mathrm{UE}}{\partial \mathrm{E}} \mathrm{G}(\mathrm{X})=0
\end{gathered}
$$

According to Formulas 4, 5, we can obtain

$$
\mathrm{P} 2=\frac{\mathrm{R}}{\mathrm{G}}(\mathrm{X})-\frac{\partial \mathrm{UE}}{\partial \mathrm{E}} / \frac{\partial \mathrm{UA}}{\partial \mathrm{A}}
$$

Similarly, if

$$
\mathrm{P} 2<\frac{\mathrm{R}}{\mathrm{G}}(\mathrm{X})-\frac{\partial \mathrm{UE}}{\partial \mathrm{E}} / \frac{\partial \mathrm{UA}}{\partial \mathrm{A}},
$$

we can obtain $\mathrm{Y}=0$.

The results show that: marginal compensation standard $=$ cost per unit ecological product - monetization utility per unit ecological product. It can be concluded that the difference between the economic cost of peasant households' participation in pollution control and the ecological benefits obtained by peasant households due to ecological improvement is the minimum compensation standard to encourage peasant households to participate in pollution control. Peasant households will not be willing to participate in the non-point source pollution control of cultivated land when the compensation standard is lower than this difference. Moreover, in the current investigation, we assumed that the farmers have the same land size and did not categorize the farmers into groups (large/small farmers). So we assumed that there is no heterogeneity prevails.

\section{Research Methods}

The ecological benefits of cultivated land are difficult to be evaluated by the existing market value evaluation methods. The selection experiment method will be used in this paper to evaluate and measure the reasonable compensation standard (Chen et al., 2020b). The selection experiment method is based on the hypothetical market to obtain stakeholders' willingness to pay or be compensated for cultivated land's ecological improvement. Assuming that the peasant household i selects the non-point source pollution control scheme $m$ of cultivated land from the $j$ attribute combination schemes of the selection set, the utility obtained is $U_{i m}$, including the deterministic term $V_{i m}$ and the random term $\varepsilon_{\mathrm{im}}$ :

$$
\mathrm{U}_{\mathrm{im}}=\mathrm{V}_{\mathrm{im}}+\varepsilon_{\mathrm{im}}
$$

The basis for the peasant household $i$ to select scheme $m$ is $U_{i m}$ $>U_{\text {in }}(m, n \in j, m \neq n)$. Assuming that $D$ is the combination of all selection sets, the probability of selection is as follows: 


$$
\begin{aligned}
\operatorname{Pim} & =\operatorname{prob}\left(\mathrm{V}_{\mathrm{im}}+\varepsilon_{\mathrm{im}}>\mathrm{V}_{\mathrm{in}}+\varepsilon_{\mathrm{in}}, \forall \mathrm{j} \in \mathrm{D}, \mathrm{n} \neq \mathrm{m}\right) \\
& =\operatorname{prob}\left(\mathrm{V}_{\mathrm{im}}-\mathrm{V}_{\mathrm{in}}>\varepsilon_{\mathrm{in}}-\varepsilon_{\mathrm{im}}, \forall \mathrm{j} \in \mathrm{D}, \mathrm{n} \neq \mathrm{m}\right)
\end{aligned}
$$

To obtain the exact expression of the above formula, assuming that $\varepsilon$ obeys Gumbel distribution and independent identical distribution, the Multinomial Logit model is obtained. At this time, the probability of consumer i selecting scheme $\mathrm{m}$ is as follows:

$$
\operatorname{Prob}(\mathrm{im})=\frac{\exp \left(\lambda V_{\mathrm{im}}\right)}{\sum_{\mathrm{ij}} \exp (\lambda \mathrm{Vij})}
$$

The linear function expression of observable utility $\mathrm{V}_{\mathrm{im}}$ is as follows:

$$
\mathrm{V}_{\mathrm{im}}=\alpha \mathrm{ASC}_{\mathrm{im}}+\beta \mathrm{x}_{\mathrm{im}}+\gamma \mathrm{iASC}_{\mathrm{im}} \mathrm{z}_{\mathrm{im}}
$$

In the above formula, $\alpha, \beta$ and $\gamma_{\mathrm{i}}$ are the parameter matrices to be estimated, $\mathrm{ASC}_{\mathrm{im}}$ is a specific alternative constant. when the alternative scheme is the benchmark scheme, ASC is assigned a value of 1 . At this time, the coefficient $\alpha_{i}$ of ASC is the possibility of peasant households selecting the benchmark scheme. If $\alpha_{i}$ is positive, peasant households are unwilling to change the traditional production mode; on the contrary, it means that peasant households are willing to accept the non-point source pollution control scheme of cultivated land. $\mathrm{X}_{\mathrm{im}}$ represents the vector-matrix of non-point source pollution control measures of cultivated land; $z_{i m}$ is the social information characteristic variable, family resource endowment, psychological perception variable, and policy cognition variable of the experiment participants; $\mathrm{ASC}_{\mathrm{im}} \mathrm{z}_{\mathrm{im}}$ is a cross term of specific alternative constant and social information characteristic variables, reflecting the influence of social information characteristic variables on participants' selection of traditional production methods.

The implied price is the marginal willingness of experiment participants to be compensated for a single non-point source pollution control measure of cultivated land, with the formula as follows:

$$
\mathrm{IP}_{\mathrm{a}}=\operatorname{MWTA}_{\mathrm{a}}=-\frac{\beta_{\mathrm{a}}}{\beta_{\mathrm{b}}}
$$

In Formula 10, $\beta_{\mathrm{a}}$ and $\beta_{\mathrm{b}}$ represent the coefficient of nonpoint source pollution control measures of cultivated land and compensation respectively. The greater IP, the higher the marginal willingness of peasant households to be compensated for non-point source pollution control measures of cultivated land.

As the change of peasant households' welfare after recovering from the benchmark scheme to the specific treatment situation, the compensation surplus is used to calculate the willingness of peasant households to be compensated WTA for non-point source pollution control scheme $\mathrm{m}$ of cultivated land in this paper, with the specific calculation formula as follows:

$$
\mathrm{WTA}_{\mathrm{m}}=\mathrm{CS}_{\mathrm{m}}=-\frac{1}{\beta \mathrm{b}}\left(\mathrm{V}_{0}-\mathrm{V}_{\mathrm{m}}\right)
$$

Where $V_{0}$ and $V_{m}$ represent the utility level of peasant households under the benchmark scheme and control scheme $\mathrm{m}$, respectively.



\section{EXPERIMENTAL DESIGN}

\section{Data Source}

The data of this paper comes from the field investigation in Changsha County, Wangcheng District, Liuyang City, Ningxiang City, Xiangtan County, and Xiangxiang City, Hunan Province (Lu et al., 2019a). A total of 289 questionnaires were distributed and collected, of which 238 were valid questionnaires. The investigation objects are mainly peasant households who have participated in cultivated land management activities and have certain expression abilities.

According to Figure 1, the areas investigated are mainly distributed in Changsha City and the surrounding two counties and cities. In recent years, the agricultural economy of Changsha City has developed rapidly, but the non-point source pollution of cultivated land caused by the surge and unreasonable use of agricultural inputs such as chemical fertilizers and pesticides, as well as the unreasonable disposal of agricultural wastes and domestic garbage, cannot be ignored. According to statistics, the proportion of high-yield farmland in cultivated land of Hunan Province has dropped from 34\% in the 1970 s to $26 \%$ at present due to the expansion and spread of agricultural non-point source pollution, and the area of water and soil loss has more than doubled compared with that in the 1960s (Lu et al., 2019b; Chen et al., 2019). Wetland resources, especially Dongting Lake Wetland, are suffering from both natural and man-made damage. $26 \%$ of cultivated land, $27 \%$ of farmland irrigation water, and $25 \%$ of farmland atmosphere have been polluted to varying degrees in Hunan Province, and more than $60 \%$ of river 




FIGURE 2 | Amount of peasant households' willingness to be compensated.

sections in the four water systems including Xiangjiang River, Zijiang River, Yuanshui River, and Lishui River have not met the requirements of fishery water quality standards (Do et al., 2019; Hong et al., 2020). Therefore, Changsha City and its surrounding counties and cities are selected as investigation objects in this paper. The compensation standard for non-point source pollution control of cultivated land is calculated, which helps to improve the local ecological environment.

\section{Selection of Experiment Attribute and Status Value Design}

In this investigation, the specific situational question designed is "Assuming that the government gives your family a certain amount of economic compensation to encourage the reduction of the use of chemical fertilizers and pesticides in the planting process of cultivated land, which scheme would you select after comprehensively considering the ecosystem value, economic loss, and compensation amount brought to your family by non-point source pollution control of cultivated land?" In order to enhance the scenario reliability, the attributes and status values of chemical fertilizer application reduction, pesticide application reduction, agricultural waste recovery, and compensation amount are selected to form attributes and status values.

Through in-depth investigation, 95\% of peasant households are willing to adopt a safe and cleaner production mode under certain economic compensation from the government, which shows that most of the peasant households are willing to improve the cultivated land environment with compensation. By taking rice planting as an example, these peasants who are willing to be compensated believe that the compensation per mu of land shall be between RMB 0 and RMB 1,000 as shown in Figure 2 . However, pre-investigation shows that the yield of rice will be reduced by about half if chemical fertilizers and pesticides are not applied. The average income per mu of ordinary rice is RMB 1,055 . In case of being converted according to this standard, about RMB 530 will be lost if chemical fertilizers and pesticides are not applied. Therefore, the upper limit of compensation amount is set at RMB 600 and divided into 6 state values, as shown in Table 1.

The source control technology of non-point source protection of cultivated land is mainly to try not to use chemical products such as chemical fertilizers and pesticides in the production process and recycle agricultural wastes such as straw. Therefore, it is formulating four attributes: chemical fertilizer application reduction, pesticide application reduction, and agricultural waste recovery rate. According to international fertilizer application standards (Dai et al., 2021; Yin et al., 2021), China needs to reduce the application of chemical fertilizer per $m u$ by about $75 \%$ to reach the average world level and reduce the application by about $50 \%$ to reach the internationally recognized safety ceiling. Thus, four status values are set, as shown in Table $\mathbf{1}$.

The questionnaire is designed for investigation according to the determined attributes and status values of non-point source pollution control of cultivated land. The three improvement measures and compensation amounts in the above table have $4,4,2$, and 7 state values, respectively, which will produce $(4 \times 4 \times$ $2 \times 7) 2=50,176$ possible selection sets. However, it is challenging to realize that in the actual investigation. Therefore, 12 representative experimental combinations are obtained through orthogonal experimental design, as shown in Table 2.

\section{RESULT AND ANALYSIS \\ Descriptive Analysis of Sample Characteristics}

As shown in Table 3, these 238 peasant households are mainly men, accounting for $87.39 \%$ of the total samples. The investigated peasant households involve all age groups, including 59 under 35 years old, 62 over 60 years old, and 117 between 35 and 60 years old, accounting for $49.16 \%$ of the total samples. The educational level of the investigated peasant households is generally not high. Only one person has an education level of university or above, accounting for $0.42 \%$ of the total samples, 44 have an education level of high school, accounting for $18.49 \%$. In contrast, more people have an educational level of junior high school and primary school, 115 and 78, respectively, accounting for 48.32 and $32.77 \%$ of the total samples. There are 141 people whose household income comes from working, accounting for $59.24 \%$. The number of people whose income comes from farming and doing business is equivalent, 45 and 48 , respectively. There are four people who rely on government relief, accounting for $1.68 \%$ of the total samples. There are 49 households with an annual household income of less than RMB 10,000 , accounting for $20.59 \%, 62$ households with an annual income of RMB 10,000-30,000, accounting for 26.05\%, 69 households with an annual income of RMB 30,000-50,000, accounting for $28.99 \%$, and 58 households with an annual income of more than RMB 50,000, accounting for $24.37 \%$.

\section{Estimated Results of MNL Model}

The estimated results are shown in Table 4. Both models pass the significance test of $1 \%$, with consistent estimation coefficients, which shows that the estimated results are robust. In addition, the fitting effect of Model 2 is better than that of Model 1 through the likelihood ratio test. Thus the results of model 2 are analyzed in this paper. 
TABLE 1 | Attributes and status values.

\begin{tabular}{ll} 
Measures & \multicolumn{1}{c}{$\begin{array}{c}\text { The basis for } \\
\text { attribute selection }\end{array}$} \\
$\begin{array}{l}\text { Chemical fertilizer application } \\
\text { reduction }\end{array}$ & $\begin{array}{l}\text { By taking nitrogen fertilizer as an example, about } 52 \% \text { enters the environment to } \\
\text { form non-point source pollution; } 5 \% \text { causes eutrophication of surface water } \\
\text { through runoff, } 2 \% \text { causes nitrate enrichment in groundwater through leaching, } \\
34 \% \text { forms acid rain or greenhouse gas through nitrification and denitrification, and } \\
\text { 11\% volatilizes to cause air pollution }\end{array}$ \\
$\begin{array}{l}\text { Pesticide application reduction } \\
\text { The average pesticide application per mu in China is } 2.5 \text { times the world average } \\
\text { level. According to the investigation, } 10-20 \% \text { of pesticides adhere to plants, }\end{array}$ \\
$\begin{array}{l}40-60 \% \text { fall on soil and water, and 5-30\% diffuse into the atmosphere } \\
\text { Agricultural waste recovery } \\
\text { rate }\end{array}$ \\
$\begin{array}{l}\text { Cultivated land waste mainly includes straw, chemical fertilizer, and pesticide } \\
\text { package and agricultural film, etc. Incineration of waste will cause severe air } \\
\text { pollution, and random disposal will cause soil hardening and water pollution and } \\
\text { endanger the survival of animals and plants } \\
\text { Compensation (RMB) is given to peasant households per mu every year when } \\
\text { implementing the control mentioned above scheme }\end{array}$
\end{tabular}

Status value

Maintain the current situation

Chemical fertilizer reduction by $25 \%$

Chemical fertilizer application reduction by $50 \%$

Chemical fertilizer application reduction by $75 \%$

Maintain the current situation

Pesticide application reduction by $25 \%$

Pesticide application reduction by $50 \%$

Pesticide application reduction by $75 \%$

All recovered in categories

Maintain the current situation

RMB 0, RMB 150, RMB 200, RMB 300, RMB 400, RMB 500 and RMB 600

TABLE 2 | Examples of selection cards in selecting experiment.

\begin{tabular}{|c|c|c|c|}
\hline Attributes & Scheme 1 & Scheme 2 & $\begin{array}{c}\text { Maintain the current } \\
\text { situation }\end{array}$ \\
\hline Chemical fertilizer application reduction & Maintain the current situation & Application reduction by $75 \%$ & Not participated \\
\hline Pesticide application reduction & Application reduction by $25 \%$ & Maintain the current situation & Not participated \\
\hline Agricultural waste recovery rate & All recovered in categories & Maintain the current situation & Not participated \\
\hline Compensation (year/mu) & RMB 200 & $\mathrm{RMB} 300$ & 0 \\
\hline
\end{tabular}

TABLE 3 | Descriptive analysis of sample characteristics.

\begin{tabular}{|c|c|c|c|}
\hline Characteristics & Groups & Frequency & Percentage (\%) \\
\hline \multirow[t]{2}{*}{ Sex } & Male & 208 & 87.39 \\
\hline & Female & 30 & 12.61 \\
\hline \multirow[t]{3}{*}{ Age } & Under 35 years old & 59 & 24.79 \\
\hline & 35-60 years old & 117 & 49.16 \\
\hline & 60 years and above & 62 & 26.05 \\
\hline \multirow[t]{4}{*}{ Educational level } & Primary school & 78 & 32.77 \\
\hline & Junior high school & 115 & 48.32 \\
\hline & Senior high school & 44 & 18.49 \\
\hline & University or above & 1 & 0.42 \\
\hline \multirow[t]{4}{*}{ Source of household income } & Farming & 45 & 18.91 \\
\hline & Working & 141 & 59.24 \\
\hline & Doing business & 48 & 20.17 \\
\hline & Government relief & 4 & 1.68 \\
\hline \multirow[t]{4}{*}{ Annual household income } & Less than $\mathrm{RMB} 10,000$ & 49 & 20.59 \\
\hline & RMB 10,000-RMB 30,000 & 62 & 26.05 \\
\hline & RMB 30,000-RMB 50,000 & 69 & 28.99 \\
\hline & More than RMB 50,000 & 58 & 24.37 \\
\hline
\end{tabular}

The coefficient of compensation is positive, indicating that compensation can effectively stimulate peasant households' willingness to participate in pollution control. The coefficient of reducing the application of chemical fertilizers and pesticides is positive, indicating that the losses brought to peasant households by reducing the application of chemical fertilizers and pesticides by $1 \%$ are 0.0068 and 0.0053 , respectively. The coefficient of agricultural waste recovery is negative, and its variable is not significant, which may be caused by the large difference in peasant households' selection preference for waste recovery in actual production. The cross-term coefficients of ASC and head of household or not, years of education, degree of part-time farming, ecological benefits, degree of risk preference, and degree of understanding of policies and measures for non-point source pollution control of cultivated land are negative. The coefficient of the cross term with age and area of cultivated land is positive, 
TABLE 4 | Empirical results of MNL model.

\begin{tabular}{|c|c|c|c|c|}
\hline \multirow[t]{2}{*}{ Variable } & \multicolumn{2}{|c|}{ Model 1 basic model } & \multicolumn{2}{|c|}{ Model 2 cross model } \\
\hline & Coefficient & SD & Coefficient & SD \\
\hline ASC & $-2.3373^{\star \star \star}$ & 0.0810 & 1.1383 & 0.8373 \\
\hline Compensation & $0.0016^{\star \star \star}$ & 0.0002 & $0.0016^{\star \star \star}$ & 0.0002 \\
\hline Chemical fertilizer application reduction & $0.0068^{\star \star \star}$ & 0.0010 & $0.0068^{\star \star \star}$ & 0.0010 \\
\hline Pesticide application reduction & $0.0053^{\star \star \star}$ & 0.0012 & $0.0053^{\star \star \star}$ & 0.0012 \\
\hline Agricultural waste recovery & -0.0588 & 0.0487 & -0.0588 & 0.0487 \\
\hline ASC_Head of the household or not & - & - & $-0.5414^{\star \star \star}$ & 0.1839 \\
\hline ASC_Age & - & - & $0.0292^{\star \star \star}$ & 0.0097 \\
\hline ASC_Years of education & - & - & $-0.0430^{*}$ & 0.0256 \\
\hline ASC_Area of cultivated land & - & - & $0.0370^{* *}$ & 0.0172 \\
\hline ASC_Degree of engaging in two or more undertakings & - & - & $-0.3489^{\star \star \star *}$ & 0.1178 \\
\hline ASC_Ecological benefit & - & - & $-0.2054^{* *}$ & 0.0941 \\
\hline ASC_Health benefits & - & - & -0.1027 & 0.0965 \\
\hline ASC_Degree of risk preference & - & - & $-0.7096^{\star \star \star}$ & 0.1256 \\
\hline ASC_Know about the policies and measures for non-point source pollution control of cultivated land or not & - & - & $-0.6951^{\star \star \star}$ & 0.0919 \\
\hline ASC_Know about ecological compensation or not & - & - & -0.016 & 0.089 \\
\hline Loglikelihood & -3156.43 & - & -3063.62 & - \\
\hline Prob > chi2 & 0.00 & - & 0.00 & - \\
\hline
\end{tabular}

${ }^{*},{ }^{* *},{ }^{* * *}$ represent significance levels of 10,5 , and $1 \%$, respectively.

TABLE 5 | Compensation standards for different restoration effects.

\begin{tabular}{|c|c|c|c|c|}
\hline \multirow{2}{*}{$\begin{array}{l}\text { Compensation } \\
\text { item }\end{array}$} & \multicolumn{2}{|c|}{ World average level } & \multicolumn{2}{|c|}{ Organic production level } \\
\hline & Attribute variation & $\begin{array}{c}\text { Compensation standard (RMB/ } \\
\text { hectare year) }\end{array}$ & Attribute variation & $\begin{array}{c}\text { Compensation } \\
\text { standard (RMB/ } \\
\text { hectare.year) }\end{array}$ \\
\hline Chemical fertilizer & $\begin{array}{l}\text { Chemical fertilizer application } \\
\text { reduction by } 73 \%\end{array}$ & 4607.70 & $\begin{array}{l}100 \% \text { Chemical fertilizer application } \\
\text { reduction by } 100 \%\end{array}$ & 6311.85 \\
\hline Pesticides & $\begin{array}{l}\text { Pesticide application reduction } \\
\text { by } 60 \%\end{array}$ & 2981.25 & $\begin{array}{l}100 \% \text { Pesticide application reduction } \\
\text { by } 100 \%\end{array}$ & 4968.75 \\
\hline Total & - & 7588.95 & - & 11280.60 \\
\hline
\end{tabular}

indicating that the younger, the higher the education level, the higher the degree of family part-time farming, the higher the recognition degree of the ecological function of non-point source pollution control of cultivated land, the higher the risk preference and the greater the willingness of heads of households with a better understanding of non-point source pollution control policies of cultivated land to participate in ecological compensation of non-point source pollution control of cultivated land. However, the larger the area of cultivated land, the more it will affect their willingness to participate in pollution control, which may be because peasant households are unwilling to change the current situation for their worries that the compensation is not enough to make up for their losses.

\section{Calculation of Compensation Standard}

Both ecological benefits and economic losses of peasant households shall be considered in the formulation of compensation standards. According to Formula 10, the marginal willingness of peasant households to be compensated for reducing the application of chemical fertilizers and pesticides by $1 \%$ is RMB $63.15 /$ ha year and RMB $49.65 /$ ha year. Ecological compensation standards with different restoration effects can be obtained from Formula (11), as shown in Table 5.
Suppose the average input of chemical fertilizers and pesticides per mu in China is reduced to the world average level. In that case, the ecological compensation standard is RMB 7,588.95/(ha year), in which the application of chemical fertilizers and pesticides needs to be reduced by 73 and $60 \%$. The compensation standards of the two are RMB 4,607.70/(ha year) and RMB 2,981.25/(ha year), respectively. Suppose the traditional production mode is restored to the organic production mode without applying any chemical fertilizers and pesticides. In that case, the ecological compensation standard is RMB $11,280.60$ /(ha year), in which the compensation standards for reducing the application of chemical fertilizers by $100 \%$ and pesticides by $100 \%$ are RMB $6,311.85 /$ (ha year) and RMB 4,968.75/(ha year), respectively.

\section{DISCUSSION}

\section{Problem Analysis}

The risk of yield reduction and the shortage of technology are also the major issues that affect peasant households' interest to participate in non-point source pollution control (Huang et al., 2019; Arning et al., 2021). Regarding the question "Do you think your rice has been polluted?" the results are shown in 




Figure 3, which shows that peasant households have a poor understanding of non-point source pollution of cultivated land. Therefore, in addition to financial compensation, in-kind compensation and technical compensation are added in this questionnaire to ask about peasant households' compensation preferences, with the results shown in Figure 4.

As can be seen from the above figure, for "water management", the compensation method selected by peasant households is mainly financial compensation, with a total of 217 households, accounting for $91.18 \%$. For "lime application", 61 households select in-kind compensation, accounting for 25.63\%; 39 households select "financial compensation", accounting for 16.39\%; 138 households select "technical compensation", accounting for $57.98 \%$. For "soil conditioner application", 113 households select in-kind compensation, accounting for 47.48\%; 107 households select financial compensation, accounting for 44.96\%; only 18 households select technical compensation, accounting for $7.56 \%$. For "organic fertilizer application", peasant households mainly select financial compensation, with a total of 177 households, accounting for $74.37 \%$; 53 households select in-kind compensation, accounting for $22.27 \%$; only 8 households select technical compensation, accounting for $3.36 \%$. For "green manure planting", the number of households selecting in-kind compensation and financial compensation is close, 104 households and 117 households, accounting for 43.70 and $49.16 \%$ respectively; 17 households select technical compensation, accounting for $7.14 \%$.

According to the results, peasant households have different compensation modes for different ways of improving the cultivated land environment. Generally speaking, peasant households selecting in-kind compensation believe that the materials provided by the government are more time-saving and labor-saving, and the quality is guaranteed compared with those that they go to the market for selection by themselves (Lu et al., 2019c; Chen et al., 2021). However, peasant households who do not select inkind compensation usually believe that in-kind compensation is lagging behind and fixed and cannot be adjusted flexibly. For peasant households selecting financial compensation, this method may be simpler and more direct, with great freedom, and coordination can be done according to their actual farming situation. Peasant households selecting technical compensation usually believe that they don't know the relevant knowledge of cultivated land management. However, they can learn and implement management measures through technical compensation provided by the government to improve the quality of their cultivated land and food.

\section{Research Limitations}

This paper mainly studies the compensation standard for nonpoint source pollution control of cultivated land in some counties and cities of Hunan Province. In order to promote the formulation of environmental protection compensation policies, further research can be carried out from the following two aspects due to the limitations of research methods and data: 1. There are significant differences between rural areas and peasant households. When formulating policies, the differentiation of compensation methods shall be appropriately

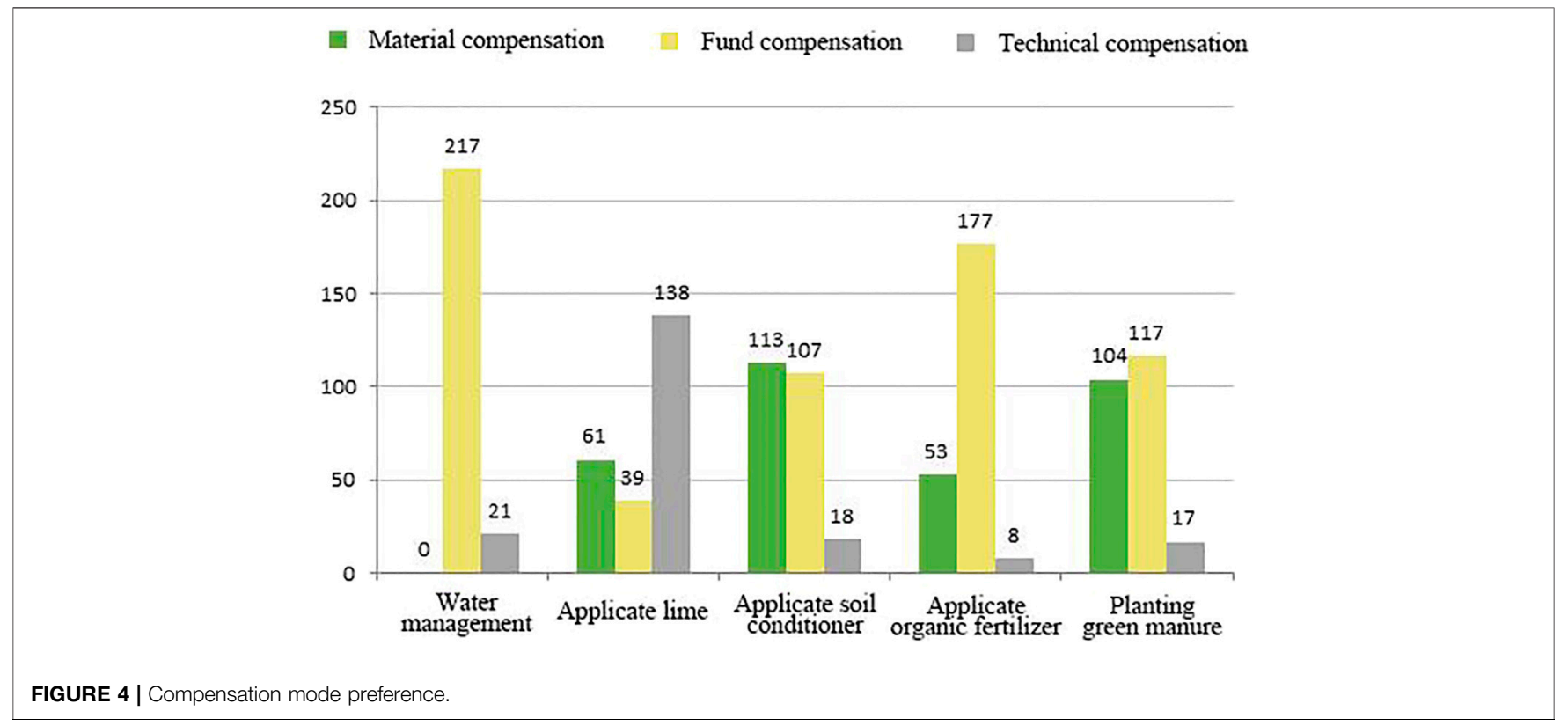


considered, which shall start from the actual situation and vital interests of peasant households as far as possible to ensure the maximum benefit of ecological compensation. 2. There are also differences in crop production and economic development in different regions. General compensation standards that can be further popularized will be obtained in the follow-up research through benefit transfer and other methods.

\section{CONCLUSION}

In this paper, the ecological benefits are included in the compensation standard for non-point source pollution control of cultivated land by using the selection experiment method and calculated. From the research results, the following conclusions and policy recommendations can be drawn:

1. According to the results, financial compensation can effectively stimulate peasant households' willingness to participate in nonpoint source pollution control of cultivated land. The compensation standards for reducing the application of chemical fertilizers and pesticides by $1 \%$ are RMB $63.15 /$ (ha year) and RMB 49.65/(ha year), respectively. Furthermore, the compensation standards for reducing the application of chemical fertilizers and pesticides in traditional production methods to the international average level and the organic production level are RMB 7,588.95/(ha year) and RMB $11,280.60$ /(ha year), respectively. The compensation standard is obtained by comprehensively considering the economic losses obtained by peasant households' participation in control and the ecosystem value. Therefore, peasant households' interest demands shall be considered when formulating ecological compensation policies. The economic losses and ecological benefits obtained by peasant households' participation in control shall be comprehensively considered.

2. Peasant households' socio-economic characteristics are quite different. Age, education level, and pollution awareness will have a significant impact on their willingness to be compensated. In addition to considering the actual situation of peasant households as much as possible when formulating policies, peasant households can also be educated on environmental protection through modern media to

\section{REFERENCES}

Arning, K., Offermann-van Heek, J., and Ziefle, M. (2021). What Drives Public Acceptance of Sustainable CO2-derived Building Materials? A ConjointAnalysis of Eco-Benefits vs. Health Concerns. Renew. Sustainable Energ. Rev. 144, 110873. doi:10.1016/j.rser.2021.110873

Chen, J., Gao, M., Mangla, S. K., Song, M., and Wen, J. (2020). Effects of Technological Changes on China's Carbon Emissions. Technol. Forecast. Soc. Change 153, 119938. doi:10.1016/j.techfore.2020.119938

Chen, J., Wang, B., Huang, S., and Song, M. (2020). The Influence of Increased Population Density in China on Air Pollution. Sci. Total Environ. 735, 139456. doi:10.1016/j.scitotenv.2020.139456

Chen, W., Pourghasemi, H. R., and Naghibi, S. A. (2018). Prioritization of Landslide Conditioning Factors and its Spatial Modeling in Shangnan improve their subjective enthusiasm to participate in nonpoint source pollution control of cultivated land.

3. In addition to the source control method of reducing application and emission, methods such as lime application and green manure planting can also improve the cultivated land environment, thus the compensation method need not be limited to the financial compensation method. Peasant households' compensation preferences for different control measures are quite different. In addition to ecological benefits, the differentiation of compensation methods shall be incorporated into the design of compensation standards for nonpoint source pollution control of cultivated land, and ecological compensation policies shall be formulated according to local conditions to maximize the benefits of ecological compensation.

\section{DATA AVAILABILITY STATEMENT}

The original contributions presented in the study are included in the article/supplementary material, further inquiries can be directed to the corresponding authors.

\section{AUTHOR CONTRIBUTIONS}

Conceptualization, SL; Formal analysis, SL; Investigation, WZ; Methodology, WZ; Software, WL; Validation, FT-H; Writing original draft, SL and WZ; Writing - review and editing, WL and FT-H. All authors have read and agreed to the published version of the manuscript.

\section{FUNDING}

The research was funded by the Sichuan Social Science Foundation of China (Grant No: 21GL223), the Key Program of the National Social Science Fund of China (Grant/Award Number: 20\&ZD095), the National Natural Science Foundation of China (Grant No: 51769012) and the new type key think tank of Zhejiang Province China Research and the grant in aid for Excellent Young Researcher of the Ministry of Education of Japan (MEXT).

County, China Using GIS-Based Data Mining Algorithms. Bull. Eng. Geol. Environ. 77, 611-629. doi:10.1007/s10064-017-1004-9

Chen, Y., Wang, Y., Liew, J. H., and Wang, P. L. (2021). Development of a Methodological Framework for Evaluating Biodiversity of Built Urban green Infrastructures by Practitioners. JOURNAL CLEANER PRODUCTIONp 303, 127009. doi:10.1016/j.jclepro.2021.127009

Chen, Z., Liang, S., Ke, Y., Yang, Z., and Zhao, H. (2019). Landslide Susceptibility Assessment Using Evidential Belief Function, Certainty Factor and Frequency Ratio Model at Baxie River basin, NW China. Geocarto Int. 34, 348-367. doi:10.1080/10106049.2017.1404143

Dai, Q., Xie, L., Guo, Z., Yang, J., Tian, G., Ma, L., et al. (2021). Develop a green Sludge Treatment: Effects of a New Additive on Sludge Properties and Co-removal of Bound Water, Organics and Toxic Elements in Sludge. J. Clean. Prod. 304, 127148. doi:10.1016/ j.jclepro.2021.127148 
Deng, X., Li, L., and Tan, Y. (2017). Validation of Spatial Prediction Models for Landslide Susceptibility Mapping by Considering Structural Similarity. Int. J. Geo-inf. 6, 103. doi:10.3390/ijgi6040103

Do, H. M., Yin, K. L., and Guo, Z. Z. (2019). A Comparative Study on the Integrative Ability of the Analytical Hierarchy Process, Weights of Evidence and Logistic Regression Methods with the Flow-R Model for Landslide Susceptibility Assessment. Geomatics Natural Hazards Risk 11, 2449-2485.

Gao, X., Shen, J., He, W., Sun, F., Zhang, Z., Zhang, X., et al. (2019). Changes in Ecosystem Services Value and Establishment of Watershed Ecological Compensation Standards. Ijerph 16, 2951. doi:10.3390/ijerph16162951

Guan, X.-j., Liu, W.-k., and Wang, H.-l. (2018). Study on the Ecological Compensation Standard for River basin Based on a Coupling Model of TPC-WRV. Water Science Technology-Water Supply 18, 1196-1205. doi:10.2166/ws.2017.183

Hong, H., Tsangaratos, P., Ilia, I., Loupasakis, C., and Wang, Y. (2020). Introducing a Novel Multi-Layer Perceptron Network Based on Stochastic Gradient Descent Optimized by a Meta-Heuristic Algorithm for Landslide Susceptibility Mapping. Sci. Total Environ. 742, 140549. doi:10.1016/j.scitotenv.2020.140549

Huang, S., Wang, L., Wang, H., Huang, Q., Leng, G., Fang, W., et al. (2019). Spatiotemporal Characteristics of Drought Structure across China Using an Integrated Drought index. Agric. Water Management 218, 182-192. doi:10.1016/j.agwat.2019.03.053

Kassouri, Y., and Altıntaş, H. (2020). Human Well-Being versus Ecological Footprint in MENA Countries: A Trade-Off? J. Environ. Manage. 263, 110405. doi:10.1016/j.jenvman.2020.110405

Lu, S. B., Zhang, Xiaoling., and Tang, Y. (2019). Evolutionary Analysis on Structural Characteristics of Water Resource System in Basins of Northern China. Sustainable Development 2020 (1), 1-13.

Lu, S., Bai, X., Zhang, X., Li, W., and Tang, Y. (2019). The Impact of Climate Change on the Sustainable Development of Regional Economy. J. Clean. Prod. 233, 1387-1395. doi:10.1016/j.jclepro.2019.06.074

Lu, S., Bai, X., Li, W., and Wang, N. (2019). Impacts of Climate Change on Water Resources and Grain Production. Technol. Forecast. Soc. Change 143, 76-84. doi:10.1016/j.techfore.2019.01.015

Lu, S., Zhang, X., Zheng, Z., and Martin, S. (2020). The Energy-Food-Water Nexus: Water Footprint of Henan-Hubei-Hunan in China. Renew. Sustainable Energ. Rev. 133, 110417. doi:10.1016/s1364-0321(20)30714-0

Lu, S., Li, J., Xiao, B., and Guo, M. (2020). Analysis of Standard Accounting Method of Economic Compensation for Ecological Pollution in Watershed. Sci. Total Environ. 737, 138157. doi:10.1016/j.scitotenv.2020.138157

Lu, S., Lian, Z., Sun, H., Wu, X., Bai, X., and Wang, C. (2021). Simulating Transboundary Watershed Water Resources Conflict. Resour. Pol. 73, 102139. doi:10.1016/j.resourpol.2021.102139

Lu, S., Zhang, X., Wang, J., and Pei, L. (2016). Impacts of Different media on Constructed Wetlands for Rural Household Sewage Treatment. J. Clean. Prod. 127, 325-330. doi:10.1016/j.jclepro.2016.03.166

Meng, Q., Miao, F., Zhen, J., Wang, X., Wang, A., Peng, Y., et al. (2016). GIS-based Landslide Susceptibility Mapping with Logistic Regression, Analytical Hierarchy Process, and Combined Fuzzy and Support Vector Machine
Methods: a Case Study from Wolong Giant Panda Natural Reserve, China. Bull. Eng. Geol. Environ. 75, 923-944. doi:10.1007/s10064-015-0786-x

Ozdemir, A. (2020). A Comparative Study of the Frequency Ratio, Analytical Hierarchy Process, Artificial Neural Networks and Fuzzy Logic Methods for Landslide Susceptibility Mapping: Taşkent (Konya), Turkey. Geotech Geol. Eng. 38, 4129-4157. doi:10.1007/s10706-020-01284-8

Sharma, S., and Mahajan, A. K. (2019). A Comparative Assessment of Information Value, Frequency Ratio and Analytical Hierarchy Process Models for Landslide Susceptibility Mapping of a Himalayan Watershed, India. Bull. Eng. Geol. Environ. 78,p 2431-2448. doi:10.1007/s10064-018-1259-9

Ulucak, R., Kassouri, Y., Çağrı İlkay, S., Altıntaş, H., and Garang, A. P. M. (2020). Does Convergence Contribute to Reshaping Sustainable Development Policies? Insights from Sub-saharan Africa. Ecol. Indic, 112.

Valentine, S. V. (2014). The Socio-Political economy of Electricity Generation in China. Renew. Sustainable Energ. Rev. 32, 416-429.

Xu, J., Xiao, Y., Xie, G., and Jiang, Y. (2019). Ecosystem Service Flow Insights into Horizontal Ecological Compensation Standards for Water Resource: A Case Study in Dongjiang Lake Basin, China. Chin. Geogr. Sci. 29, 214-230. doi:10.1007/s11769-019-1025-3

Yin, J., Zhang, X., Huang, W., Liu, L., Zhang, Y., Yang, D., et al. (2021). The Potential Benefits of Dietary Shift in China: Synergies Among Acceptability, Health, and Environmental Sustainability. Sci. Total Environ. 779, 146497. doi:10.1016/j.scitotenv.2021.146497

Zhao, Y., Wu, F.-p., Li, F., Chen, X.-n., Xu, X., and Shao, Z.-y. (2021). Ecological Compensation Standard of Trans-boundary River Basin Based on Ecological Spillover Value: A Case Study for the Lancang-Mekong River Basin. Ijerph 18, 1251. doi:10.3390/ijerph18031251

Zheng, Q., Wan, L., Wang, S., Wang, C., and Fang, W. (2021). Does Ecological Compensation Have a Spillover Effect on Industrial Structure Upgrading? Evidence from China Based on a Multi-Stage Dynamic DID Approach. J. Environ. Manage. 294, 112934. doi:10.1016/j.jenvman.2021.112934

Conflict of Interest: The authors declare that the research was conducted in the absence of any commercial or financial relationships that could be construed as a potential conflict of interest.

Publisher's Note: All claims expressed in this article are solely those of the authors and do not necessarily represent those of their affiliated organizations, or those of the publisher, the editors and the reviewers. Any product that may be evaluated in this article, or claim that may be made by its manufacturer, is not guaranteed or endorsed by the publisher.

Copyright $\odot 2021 \mathrm{Lu}$, Zhong, Li and Taghizadeh-Hesary. This is an open-access article distributed under the terms of the Creative Commons Attribution License (CC $B Y$ ). The use, distribution or reproduction in other forums is permitted, provided the original author(s) and the copyright owner(s) are credited and that the original publication in this journal is cited, in accordance with accepted academic practice. No use, distribution or reproduction is permitted which does not comply with these terms. 